\title{
ТЕОРЕТИЧНІ ЗАСАДИ ВИЗНАЧЕННЯ СТРУКТУРИ СОЦІАЛЬНОЇ ІДЕНТИЧНОСТІ ОСОБИСТОСТІ
}

Розглянуто структуру соціальної ідентичності особистості та визначено її складові, уточнено й узагальнено саме поняття соціальної ідентичності, розширено та доповнено їі структуру. Наголошується, що всі соціальні групи, до яких належить людина, характеризуються критеріями членства й межами, отож належність до раси, національність, етнічність, належність до релігійної конфесії, а також соціальні класи, політична ідеологія, навіть статеве самовизначення виконують важливі функції як на груповому, так і на міжособовому рівні. Аналізується формування соціальної ідентичності, завдяки якій суспільство отримує можливість долучати індивідів до системи соціальних зв'язків і відносин, а особистість реалізовує свою базову потребу в груповій належності, що забезпечує захист, можливості самореалізації, оцінки з боку інших та впливу на групу. Ідентичність представлено як один 3 механізмів пізнання та розуміння іншої людини. Зроблено висновок, що орієнтація на іншу людину як на зразок істотно підвищує показники соціального самовизначення.

Ключові слова: соціальна ідентичність, етнічна ідентичність, Я-концепція, соціальні ролі, соціальна позиція, конформізм.

Постановка проблеми. У результаті попередніх досліджень [8] було виявлено, що побудова нової картини життєвого світу відбувається шляхом оцінювання змін у суспільстві, переоцінки старої системи цінностей і трансформації їі в якісно нову. Так формуються індивідуальні стратегії подолання проблем, що стають новими нормами моделей життєдіяльності. І. Я. Іванюк [6], зокрема, зазначає, що процес успішної адаптації передбачає сформованість як особистісної ідентичності, так і соціальної, адже, пристосовуючись до мінливої соціальної реальності, особистісна ідентичність зазнає змін, що призводять до криз розвитку особистості та активного осмислення нею свого місця в суспільстві та світі, своїх цілей, цінностей, мотивів та переконань. Соціальна ідентичність виконує роль самопрезентації, $є$ формою самоопису себе в зовнішньому світі, поєднанням зв'язків, відносин та оцінок, що виявляється як усвідомлення індивідом свого місця в соціумі.

Феномен соціальної ідентичності, їі структура завжди цікавили зарубіжних і вітчизняних дослідників, але поза їхньою увагою досі залишалися питання ролі структурних компонентів соціальної ідентичності в їі становленні як єдиного цілісного процесу.

Аналіз останніх досліджень $і$ публікацій. Проблема ідентичності привертала увагу дослідників як раніше, так і останнім часом. У західній науковій традиції дослідження спрямовувалися переважно на вивчення 
особистісної мотивації (Е. Еріксон, Дж. Марсія, 3. Фройд, К. Юнг та ін.), взаємодію осіб у малих контактних групах (Дж. Мід, Г. Теджфел, Дж. Тернер та ін.) або ж ці підходи поєднувалися (М. Брюер, Т. Тайлер). Дослідження ідентичності у вітчизняній психології представлені доробком М. О. Шульги, П. І. Гнатенка та В.М.Павленко, І. Г. Губеладзе, С. О. Макєєва, а також Н. В. Антонової, Є. І. Головахи, О. Г. Злобіної, А. В. Зубенка, Н. В. Костенко, В. С. Малахова, В.М.Павленка, Л. Г. Чорної та ін.

Проблема аналізу структури соціальної ідентичності та їі цілісності порушується в працях багатьох дослідників, адже основна ії функція полягає в цілісності та неперервності Я (Н. М. Миронова, У. Дойз, Ч. Кулі, Г. МакКолл, Дж. Сіммонс, С. Стрікер). Утім, багато хто 3 дослідників розглядав соціальну ідентичність як феномен, а не певну цілісність (М. Бревер, Д. Майєрс, С. Холл, М. Ярумович). Ще один напрям досліджень представляє соціальну ідентичність як окремі види ідентичності - етнічну, професійну, статеву, громадянську тощо.

Meта статmi: виокремити теоретичні засади визначення структури соціальної ідентичності як чинника адаптації особистості та визначити ії̈ складові.

Виклад основного матеріалу дослідження. Предметом нашого аналізу стали теоретичні погляди на структуру соціальної ідентичності особистості та виокремлення ії складових. Під структурою ми розуміємо наведене в "Психологічному словнику" [11] визначення поняття: це сукупність зв'язків між компонентами об'єкта, що забезпечують його цілісність та відповідність самому собі. Соціальну ідентичність можна розглядати як самопрезентацію, як форму самоопису себе в зовнішньому світі, як поєднання зв'язків, відносин та оцінок, які означують структуроване місце індивіда в соціумі. Соціальна ідентичність має декілька видів (гендерна, етнічна, професійна тощо), що пов'язано з належністю індивіда до різних соціальних груп. Ці види є регулятором діяльності людини, iї системотвірним елементом. Так, якщо соціальна ідентичність виявляється в усвідомленні належності до групи, а також прийнятті іiі цінностей, норм, настановлень, стереотипів тощо, то $з$ певною ймовірністю ми можемо говорити про прогнозування поведінки особистості залежно від того, яка в неї ідентичність.

Н. Л. Іванова, яка досліджувала структуру соціальної ідентичності, дійшла висновку, що вона являе собою “сукупність стійких зв'язків між компонентами ідентичності, які забезпечують ії цілісність і тотожність самій собі" [7, с. 133]. Функція соціальної ідентичності полягає в збереженні ідентичності, але водночас і в пристосуванні до нових умов. Кожна підструктура соціальної ідентичності, як зазначалося вище, утворена взаємопов'язаними елементами, що можуть бути самостійними об'єктами дослідження. 
Наразі зроблено чимало спроб дослідити та впорядкувати структуру соціальної ідентичності (О. П. Бєлінська, О. О. Тихомандрицька, Ю. Я. Кисельов, Т. Г. Стефаненко, В. О. Ядов, Л. Чанте, У. Дойз). Дослідники дійшли висновку, що кількість ідентичностей загалом обмежена й вони утворюють певну ієрархічну структуру. Оскільки не всі уявлення про своє членство $є$ значущими, кількість ідентичностей не може бути значною. Нас цікавить саме набір компонентів структури ідентичностей, серед яких етнічна ідентичність, Я-концепція, соціальні ролі та соціальна позиція, конформізм.

Етнічна ідентичність як у минулому, так і на сучасному етапі досліджень вивчається як складова соціальної ідентичності, про що свідчать численні дослідження зарубіжних і вітчизняних учених (Н. Л. Баліч, М. М. Губогло, Л. М. Дробижева, В. М. Муха, Т. Г. Стефаненко, Дж. С. Фінні). За визначенням Т. Г. Стефаненко, етнічна ідентичність $\epsilon$ "складовою частиною соціальної ідентичності особистості, психологічною категорією, що стосується до усвідомлення своєї належності до певної етнічної спільноти" [13, с. 183]. Також дослідниця наголошує на тому, що слід розмежовувати поняття етнічної ідентичності та поняття етнічності, де останнє є соціологічною категорією і визначається як етнічна належність за певними об'єктивними ознаками (наприклад, етнічна належність батьків, місце народження, мова, культура, тощо). Етнічна ідентичність не є декларованою ідентичністю, тобто це не зарахування себе до певної етнічної спільності, що виявляється лише в назві. Отже, Т. Г. Стефаненко визначає поняття етнічної ідентичності як результат когнітивно-емоційного процесу усвідомлення себе представником етносу, певний ступінь ототожнення себе з ним i відокремлення від інших етносів.

Процес набуття особистістю ідентичності $\epsilon$ похідною від Я-концепиіï. Коли відбувається прийняття власного образу, людина втілює його в певній поведінці, діяльності тощо. Ідентичність як самовизначення реалізується за допомогою поєднання компонентів Я-концепції. В. І. Сметаняк зазначає, що самосвідомість є відображенням внутрішнього світу: “протилежне усвідомленню зовнішнього світу переживання єдності і специфічності “Я” як автономної (окремої) сутності, що наділена думками, почуттями, бажаннями, здатністю до дії” [12, с. 331]. У. Дойз також розглядає структуру соціальної ідентичності як набір п'яти основних компонентів Я-концепції, серед яких етнічна ідентичність, академічні можливості, спорт, популярність та образ тіла. Проаналізувавши взаємозв'язок цих компонентів із самоповагою, він зробив висновок, що для формування самоповаги та соціальної ідентичності дуже важливими є норми і спільні цінності, які дають змогу подолати культурні бар'єри [16]. 
У праці Р. Бернса Я-концепція та ії структура розглядаються на основі аналізу теорій Е. Еріксона про ідентичність. Дослідник зазначає, що терміни “ідентичність” і “Я-концепція” для нього є синонімами. Він розглядає структуру Я-концепції у вигляді ієрархії та виокремлює при цьому три іiї основні модальності: реальне Я (власні настановлення щодо сприйняття здібностей, ролей, статусу індивіда); дзеркальне, або соціальне Я (власні настановлення щодо уявлень про погляди інших на себе); ідеальне Я (настановлення уявлень індивіда про себе в майбутньому). Далі Р. Бернс зазначає, що ідентичність набувається різними шляхами, але найбільш оптимальною $є$ така, що усвідомлена й активна. Така ідентичність передбачає, що індивід робить власний свідомий вибір, контролює своє життя та здійснює ціннісне самовизначення, а це веде до формування позитивної Я-концепції. Отже, під час взаємодії когнітивного, афективного та оцінно-вольового компонентів Я-концепції відбувається виокремлення себе як індивідуальності [2].

Ще однією складовою соціальної ідентичності є соиіальна роль. Соціальна роль - це певна модель поведінки, обумовлена статусом i спрямована на виконання обов'язків та прав, які визначаються нормами, зазначає Н. Б. Челдишова [14]. Тобто це певні очікування і вимоги, які транслюються соціальною групою щодо індивіда, який має певний статус. Так, соціальна роль тісно пов'язана із соціальною позицією індивіда в суспільстві. Соціальні ролі виникають та приймаються в певних ситуаціях та можуть мати різне спрямування, що називається рольовим набором. На думку П. Бергера, виконавець ототожнює себе зі своєю роллю, що відбувається в процесі ідентифікації, тобто за кожною соціальною роллю стоїть своя певна, “епізодична" ідентичність. Дослідник зазначає, що індивід може різною мірою ототожнювати себе із статусами та ролями [1].

Розвиваючи думки П. Бергера, А. І. Кравченко висновує, що деякі ролі людина може виконувати без внутрішньої згоди, а статус ролі здатний впливати на ії виконання (див. [9]). Зокрема, що вищий статус, то більша внутрішня згода, а що нижчий статус, то внутрішня згода нижча. У разі максимального злиття з роллю відбувається рольова ідентифікація, а в разі середнього або мінімального злиття - дистанціювання від ролі. Слід розрізняти дистанціювання і міжстатусну дистанцію, що проявляється в спілкуванні між людьми, які займають різні щаблі статусів (наприклад, підлеглий і керівник). Дистанціювання полягає у віддаленні саме від своєї ролі, а не у віддаленні від іншої людини. А. І. Кравченко зазначає, що ідентифікація відбувається не завжди однаково, а залежно від іiі значущості або від значущості статусу [там само]. Такі ідентифікації дослідник називає рольовою системою. Рольову систему підтримує і трансформує суспільство, де згодом рольова система перетворюється в ідентичність. 
Е. Гідденс, вивчаючи ідентичність, висунув гіпотезу структури ідентичності. Він вважав іï двополюсною, де, з одного боку, конформізм як пристосування людини до соціальних норм, а 3 другого - замкненість на собі. Між цими двома полюсами дослідник виокремлює рівні: 1) уніфікації - фрагментації; 2) безпорадності - оволодівання; 3) авторитарності - невизначеності; 4) особистісних потреб - "ринкового" індивіда. Крім того, до цієї структури він додав патологічні форми розвитку на кожному з рівнів: традиціоналізм - конформізм; усемогутність - відчуження; догматизм - радикальний сумнів; нарцисизм повне розчинення у світі товарів [4].

Вітчизняні дослідники також вивчали конформізм як структурний елемент соціальної ідентичності. Так, І. А. Мейжис і Л. Г. Почебут розглядають соціальну ідентичність як настановлення людини на свої стосунки 3 конкретною соціальною групою, тобто як належність до групи. Власне, соціальну ідентичність вони ототожнюють 3 поняттям “групова ідентичність”, виокремлюючи при цьому три їі компоненти: когнітивний, емоційний та поведінковий. Дослідниці зробили висновок, що поведінка конкретної людини залежить від думки та поведінки інших людей, а в разі конфлікту між сенсорною та соціальною інформацією виграє соціальна. Конфлікти між соціальною інформацією різних ступенів призводять до неоднозначного розв'язання проблеми та відбуваються в процесі вибору між приєднанням до думки групи i самодостатністю, упевненістю у своїй думці [10].

Відтак у цьому феномені відбивається проблема відповідності між вербальною реакцією та дійсною поведінкою і думками людини. Звідси випливає, що існує два види конформізму - раціональний і мотиваційний: раціональний визначається зміною когнітивної структури (поведінка змінюється внаслідок переконування індивіда за допомогою аргументів та фактів, тягне за собою аналіз та переосмислення нової інформаціі), а мотиваційний показує лише зміну поведінки, “демонстрацію" згоди задля певного мотиву.

Висновки. На основі проведеного теоретичного аналізу зроблено спробу побудувати власну авторську структуру соціальної ідентичності. При цьому за основу взято теоретичні розробки I. О. Бондаревської, яка розглядає соціальну ідентичність під кутом зору групової подібності та членства в групах, де соціальна ідентичність відображає почуття спільності з іншими людьми та складається з чотирьох прошарків [3]. У центр моделі поміщено цінності, які найменше піддаються змінам, за цінностями йдуть атитюди, що більше, ніж цінності, зазнають змін. Третім і четвертим прошарками є стиль міжособової взаємодії та поведінка в конкретній ситуації взаємодії, де остання найбільше піддається змінам. Перший і другий прошарки об'єднуються в змістовому (смисловому) наповненні, а два останні - у стилі міжособової взаємодії, де 
він і виявляється. Запропонована нами модель розширює зміст соціальної ідентичності і до змістового наповнення додає соціальні ролі, статусні позиції, конформність та самооцінку як такі, що локалізуються між атитюдами і стилем міжособової взаємодії, які можуть зазнавати значних змін.

3 огляду на результати дослідження Н. М. Лебедєвої, яка виявила, що локус контролю впливає на вихід особистості із кризи соціальної ідентичності, вважаємо також за потрібне включити локус контролю в теоретичну модель дослідження структури соціальної ідентичності та обгрунтувати це в подальших наших дослідженнях.

\section{Лimepamypa}

1. Бергер П. Л. Общество в человеке / П. Л. Бергер // Социологический журнал. - 1995. - № 2. - С. 162-180.

2. Бернс Р. Что такое Я-концепция / Р. Бернс // Развитие Я-концепции и воспитание : пер. с англ. / Р. Бернс. - Москва : Прогресс, 1986. - С. 30-66.

3. Бондаревська I. Теоретичні підходи до вивчення соціальної ідентичності / І. Бондаревська // Соціальна психологія. - 2011. - № 4 (48). - С. 14-25.

4. Гидденс Э. Устроение общества: Очерк теории структурации / Энтони Гидденс. - 2-е изд. - Москва : Академ. Проект, 2005. - 528 с.

5. Губеладзе I. Г. Сільська молодь у місті: пошук ідентичності : монографія / І. Г. Губеладзе. - Київ : Міленіум, 2015. - 236 с.

6. Іванюк I. Я. Становлення ідентичності особистості в контексті зарубіжної психології [Електронний ресурс] / І. Я. Іванюк // Освіта регіону. - 2010. № 1. - Режим доступу : http://www.social-science.com.ua

7. Иванова Н. Л. Психологическая структура социальной идентичности : дис. ... д-ра психол. наук: 19.00.05 / Иванова Наталья Львовна. Ярославль, 2003. - 408 с.

8. Коваленко А. Б. Соціальна ідентичність як механізм адаптації особистості під час суспільної кризи / А. Б. Коваленко, К. С. Безверха // Український психологічний журнал : зб. наук. праць / КНУ імені Тараса Шевченка. Київ, 2017. - № 1(3). - С. 48-63.

9. Кравченко С. А. Социология: парадигмы через призму социологического воображения : учеб. для вузов / С. А. Кравченко. - Москва : Экзамен, 2004. $-624 \mathrm{c}$.

10. Мейжис И. Социальная психология / И. Мейжис, Л. Почебут. - СанктПетербург : Питер, 2010. -672 с.

11. Психологический словарь / под общ. ред. А. В. Петровского, М. Г. Ярошевского. - 2-е изд., испр. и доп. - Москва : Политиздат, 1990. - 494 с.

12. Сметаняк B. I. Особистісна ідентичність як функція Я-концепції / В. І. Сметаняк // Збірник наукових праць Інституту психології ім. Г. С. Костюка АПН України. - Київ, 2007. - Т. 9. - Ч. 4. - С. 331-338.

13. Стефаненко Т. Г. Этнопсихология / Т. Г. Стефаненко. - 4-е изд., испр. и доп. - Москва : Аспект Пресс, 2009. - 368 с.

14. Челдышова Н. Б. Шпаргалка по социальной психологии / Н. Б. Челдышова. - Москва : Экзамен, 2007. - 48 с. 
15. Чорна Л. Г. Ідентичність особи: від групи до індивідуальності (методологічний аналіз) / Л. Г. Чорна // Проблеми політичної психології та її роль у становленні громадянина Української держави : зб. наук. праць / Асоц. політ. психологів України, Ін-т соц. та політ. психології НАПН України. Київ : Міленіум, 2012. - Вип. 13. - С. 108-118.

16. Doise W. Social Representations in Personal Identity / W. Doise // Social Identity (international perspectives). - London-New Delhi, 1998. - P. 13-24.

\section{References}

1. Berger, P. L. (1995). Obshchestvo v cheloveke [Society in Man]. Sotsiologicheskiy zhurnal [Sociological Journal], 2, 162-180 (rus).

2. Berns, R. (1986). Chto takoye Ya-kontseptsiya [What is the self-concept]. Razvitiye Ya-kontseptsii $i$ vospitaniye [Development of self-concept and education], pp. 30-66. Moscow: Progress Publ. (rus).

3. Bondarevska, I. (2011). Teoretychni pidkhody do vyvchennia sotsialnoi identychnosti [Theoretical Approaches to the Study of Social Identity]. Sotsialna psykholohiia [Social Psychology], 4 (48), 14-25 (ukr).

4. Giddens, A. (1984). Ustroyeniye obshchestva: Ocherk teorii strukturatsii [The Constitution of Society: Outline of the Theory of Structuration]. University of California Press.

5. Hubeladze, I. H. (2015). Silska molod u misti: poshuk identychnosti [Rural youth in the city: search for identity]. Kyiv: Millenium Publ. (ukr).

6. Ivaniuk, I. Ya. (2010). Stanovlennia identychnosti osobystosti [Formation of the identity of the individual in the context of foreign psychology]. Osvita rehiony [Education of the region], 1, http://www.social-science.com.ua (ukr).

7. Ivanova, N. L. (2003). Psikhologicheskaya struktura sotsialnoy identichnosti [Psychological structure of social identity]. D. Sc. Thesis, Yaroslavl, Russia (rus).

8. Kovalenko, A. B., \& Bezverkha, K. S. (2017). Sotsialna identychnist yak mekhanizm adaptatsii osobystosti pid chas suspilnoi kryzy [Social identity as a mechanism for adaptation a person in times of social crisis]. Ukrainskyi psykholohichnyi zhurnal [Ukrainian psychological journal], 1(3), 48-63 (ukr).

9. Kravchenko, S. A. (2004). Sotsiologiya: paradigmy cherez prizmu sotsiologicheskogo voobrazheniya [Sociology: paradigms through the prism of sociological imagination: study for high schools]. Moscow: Examination Publ. (rus).

10. Meyzhis, I., \& Poshebut, L. (2010). Sotsialnaya psikhologiya [Social psychology]. St. Petersburg: Piter Publ. (rus).

11. Petrovskiy, A. V., \& Yaroshevskiy, M. G. (Eds.). (1990). Psikhologicheskiy slovar [Psychological dictionary]. 2nd ed., corrected and add. Moscow: Politizdat Publ. (rus).

12. Smetaniak, V. I. (2007). Osobystisna identychnist yak funktsiia Ya-kontseptsii [Personality Identity as a Function of the I-Concept]. Zbirnyk naukovykh prats Instytutu psykholohii imeni H. S. Kostiuka APN Ukrainy [Collection of Scientific Papers. G. S. Kostiuk Institute of Psychology of the Academy of Pedagogical Sciences of Ukraine], vol. 9, part 4, pp. 331-338 (ukr).

13. Stefanenko, T. G. (2009). Etnopsikhologiya [Ethnopsychology]. 4th ed. corrected and add. Moscow: Aspect Press Publ. (rus).

14. Cheldyshova, N. B. (2007). Shpargalka po psikhologii [Cheat sheet on social psychology]. Moscow: Examination Publ. (rus). 
15. Chorna, L. H. (2012). Identychnist osoby: vid hrupy do induvidualnosti (metodolohichnyi analiz) [Identity of a person: from group to individuality (methodological analysis)]. Problemy politychnoi psykholohii ta yii rol u stanovlenni hromadianyna Ukrainskoi derzhavy [Problems of political psychology and its role in the formation of a citizen of the Ukrainian state], 13, 108-118 (ukr).

16. Doise, W. (1998). Social Representations in Personal Identity. Social Identity (international perspectives). London-New Delhi, pp. 13-24.

\section{Kovalenko A. B., Bezverkha K. S. Theoretical Principles of Definition} of the Structure of Social Identity of Personality

It is outlined the structure of social identity and defines components, the concept of social identity is elaborated and generalized, social identity structure is expanded and supplemented. All social groups to which a person belongs are characterized by membership criteria and boundaries - membership of a religious denomination, nationality, membership in race, ethnicity, also social classes, political ideology, even sexual self-fulfillment performs important functions both on the group and on the interpersonal levels. Thus, a social identity is formed, where society gets an opportunity to include individuals in the system of social relations and relationships, and the individual realizes the basic need for group membership that provides protection, opportunities for self-realization, assessment from others and influence on the group. Identity is also one of the mechanisms of knowledge and understanding of another person. Orientation to another person, for example, significantly increases the rates of social self-determination.

Key words: social identity, ethnic identity, self-esteem, social roles, social position, conformism.

(C) Коваленко А. Б., Безверха К. С. 